\title{
KETERAMPILAN MEMBERIKAN PERHATIAN \\ DALAM KONSELING DAN TELAAH AYAT ALQURAN
}

\author{
Thalib \\ STAIN Datokarama Palu, Jl. Diponegoro 23 Palu \\ e-mail: tlbstain@yahoo.co.id
}

\begin{abstract}
The purpose of this study was to investigate attending skill in counseling and quranic verses. This study was conducted employing descriptive-qualitative method. The data were collected from written sources and quarnic verses through five phases (1) analyzing theory, (2) collecting apparopriate quranic verses, (3) classifying relevant quranic verses, (4) doing discussion; and (5) drawing conslusion. The results of this study indicated that from 27 quranic verses studied, there were six verses relevant to the concept of attending skill in counseling; two verses relevant enough; seven verses lack of relevance; and twelve verses irrelevant.

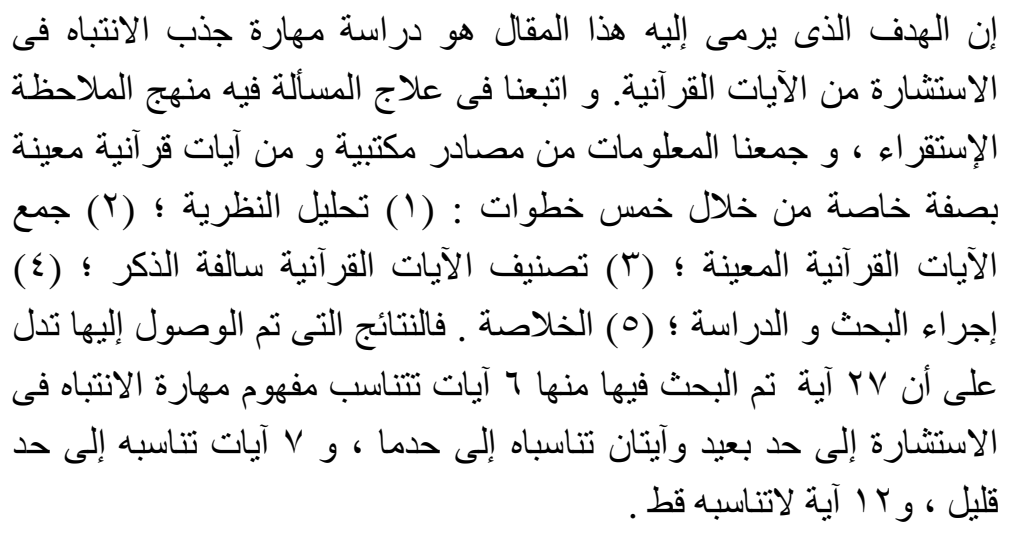

Kata Kunci: attendind skill, konseling, ayat Alquran 


\section{PENDAHULUAN}

Era global yang ditandai dengan perkembangan ilmu pengetahuan dewasa ini berjalan begitu cepat dan pesat dalam berbagai bidang kehidupan, termasuk bidang pendidikan. Salah satu bidang ilmu pengetahuan yang berkembang pesat saat ini adalah bimb.gan dan konseling yang berlndaskan psikologi. Perkembangan ini terkait dengan usaha untuk memahami kehidupan manusia serta membantu memecahkan berbagai problem hidupnya.

Di Barat saat ini, perkembangan perb.cangan tentang konseling dan proses hubungan yang bertujuan membantu (helping relationship) yang didasarkan pada nilai-nilai agama, merupakan trend baru. Perkembangan itu berawal dari berkembangnya aliran konseling psikodinamika, behaviorisme, humanisme, dan multikultural, hingga sekarang ini tengah berkembang konseling spiritual sebagai kekuatan kelima selain keempat kekuatan terdahulu (Stanard, Singh, \& Painter, 2000:204). Salah satu penyebab berkembangnya konseling spritual ini adalah berkembangnya konseling religius.

Perkembangan konseling religius ini dapat dilihat dari beberapa hasil laporan jurnal penelitian berikut. Pertama, Stanard, Singh, dan Painter (2000:204) melaporkan bahwa telah muncul suatu era baru tentang penyembuhan melalui kepercayaan, keimanan, dan imajinasi selain melalui penjelasan rasional tentang sebab-sebab fisik dan akibatnya sendiri; kedua, hasil penelitian Chalfant dan Heller (dalam Genia, V., 1994:396) menyatakan bahwa banyak orang berada dalam kesusahan emosional beralih ke konselor religius. Riset yang dilakukan selama rentang 20 tahun menunjukkan bahwa sekitar 40 persen orang yang mencari bantuan untuk masalah psikologis lebih memilih berkonsultasi ke pendeta atau tokoh agama daripada ke para profesional kesehatan mental lainnya; dan ketiga, Lovinger dan Worthington (dalam Keating \& Fretz, 1990:293) menyatakan bahwa klien yang religius memandang negatif konselor yang bersikap sekuler sehingga seringkali mereka menolak dan bahkan menghentikan terapi secara dini.

Nilai-nilai agama yang dianut klien merupakan satu hal yang perlu dipertimbangkan helper (pemberi bantuan) dalam memberikan bantuan kepada helpee (orang yang diberi bantuan), sebab helpee yang fanatik dengan ajaran agamanya, akan sangat yakin terhadap 
pemecahan masalah pribadinya melalui nilai-nilai dalam ajaran agamanya. Nilai-nilai agama (relegius values) penting untuk dipertimbangkan oleh helper (pemberi bantuan) dalam proses pemberian bantuan sehingga proses pemberian bantuan menjadi efektif. Senada dengan pendapat tersebut Courtland (1992) berpendapat bahwa suatu ajaran yang inheren dengan agama dan keyakinan spiritual dapat mempengaruhi seluruh aspek perkembangan dan interaksi kehidupan manusia.

Corey (2000) selanjutnya mengemukakan bahwa spiritual berperan secara integral dan esensial dalam perkembangan kepribadian individu, telah meraih momen tempat dan kebangkitannya saat ini sehingga hal ini mengalami peningkatan kepedulian terhadap spiritual klien pada abad XXI ini.

Berkembangnya kecendrungan sebagian masyarakat dalam mengatasi permasalahan kejiwaan, yang mendorong mereka meminta bantuan kepada para agamawan, telah terjadi di dunia Barat yang sekuler. Hal serupa menurut pengamatan penulis, juga telah terjadi di Indonesia yang masyarakatnya religius. Hal ini antara lain dapat diamati di masyarakat, banyak orang yang datang ke tempat para kyai bukan untuk menanyakan masalah hukum agama, tetapi justeru mengadukan permasalahan kehidupan pribadinya untuk meminta bantuan jalan keluar, baik berupa nasihat, saran, meminta doa-doa dan didoakan untuk kesembuhan dari penyakit, maupun keselamatan dan ketenangan jiwa. Begitu pula kalau memperhatikan acara "Gema Rohani" di RCTI dan SCTV (minggu sore), kita sering menyaksikan tayangan orang-orang yang mengalami permasalahan hidup, mengalami sakit, baik secara fisik maupun psikis. Mereka mengaku sembuh setelah berkonsultasi dengan pendeta atau pastor untuk meminta bimb.gan doa dan melakukan petunjuk dan nasihat dari para pendeta atau pastor tersebut. Walaupun data ini belum didukungan oleh peneltian yang akurat tentang seberapa persen jumlah masyarakat yang melakukan hal ini, hal tersebut merupakan realitas yang terjadi di masyarakat kita sekarang ini. Kondisi ini tampaknya sesuai dengan pendapat Jung (dalam Brian, et. al, 2000) yang menyatakan bahwa ide tentang moral dan Tuhan memiliki inti dari jiwa manusia yang tidak dapat terhapus. Oleh karena itu, mengapa setiap psikolog yang jujur harus memahami fakta ini. Ide ini tidak dapat dijelaskan atau "dibunuh" dengan ironi. Hal yang terungkap dalam psikologi ini 
merupakan fakta yang harus dipertimbangkan, seperti pada saat kita berhadapan dengan pengaruh, insting, dan sebagainya.

Berdasarkan pandangan di atas, dapat dikemukakan bahwa abad ke-21 ini merupakan era baru dalam memecahkan persoalan yang dihadapi oleh manusia. Pemecahan masalah tersebut tidak dapat mengandalkan prinsip-prinsip ilmiah tetapi lebih daripada itu adalah prinsip-prinsip agama. Dalam konteks ini, agama memegang peranan yang strategis untuk membantu memecahkan setiap masalah yang dihadapi oleh manusia agar tetap eksis dalam menjalankan aktivitas kehidupannya. Agama merupakan faktor esensial dan integral bagi kehidupan manusia. Pelibatannya dalam proses pemberian bantuan sangat penting. Gambaran ini menunjukkan pentingnya pengembangan keterampilan konseling atau keterampilan memberikan bantuan (helping relationship) yang berwawasan agama, terutama dalam rangka menghadapi klien yang berpegang kuat pada nilai-nilai ajaran agamanya.

Menurut konsep pemberian bantuan (helping relationship) atau konseling, seorang pemberi bantuan (helper) harus memiliki dua keterampilan, yaitu keterampilan komunikasi dasar konseling dan keterampilan konseling. Dari kedua keterampilan yang harus dimiliki oleh pemberi bantuan atau konselor, salah satu di antaranya yang akan dikaji dalam penelitian ini adalah keterampilan komunikasi dasar konseling atau keterampilan komunikasi pemberi bantuan (helper). Keterampilan komunikasi dasar ini akan dikaji dari Alquran sebagai sumber utama ajaran agama Islam.

Menurut Alquran, ilmu pengetahuan bersumber dari dua jalan, yaitu pertama, bersumber dari ayat-ayat kauniyyah, yaitu alam semesta yang diciptakan Allah, dan bergerak sesuai dengan ketentuan Allah. Keterangan ini sesuai firman Allah: Sesungguhnya dalam penciptaan langit dan bumi, silih bergantinya malam dan siang terdapat tanda-tanda bagi orang-orang yang berakal (Q.S Âli Imrân [3]:190). Apakah mereka tidak memperhatikan unta bagaimana dia diciptakan?, langit bagaimana ia ditinggikan?, gunung-gunung bagaimana ia ditegakkan?, dan bumi bagaimana ia dihamparkan? (Q.S Al-Ghâsiyah [88]:17-18). Dan dalam dirimu, apakah kamu tidak perhatikan? (Q.S Al-Dzâriyat [51]:21). Beberapa ayat di atas menunjukkan bahwa alam semesta ini dengan segala isinya merupakan ayat-ayat Allah yang harus diteliti dan dipelajari untuk 
melahirkan ilmu pengetahuan demi kemaslahatan umat manusia; dan kedua, bersumber dari ayat-ayat qauliyyah, yaitu kitab suci Alquran sebagai petunjuk bagi manusia. Keterangan ini sesuai dengan firman Allah: Sesungguhnya Alquran ini memberikan petunjuk kepada (jalan) yang lebih lurus dan memberi kabar gembira kepada orangorang mu'min yang mengerjakan amal shaleh bahwa bagi mereka ada pahala yang besar (Q.S Al-Isrâ' [17]:9). Sesungguhnya telah Kami mudahkan Alquran untuk pelajaran, maka adakah orang yang mengambil pelajaran (Q.S Al-Qamr [34]:40).

Hasil penelitian dan kajian ini, baik dari ayat kauniyyah maupun qauliyyah dalam masalah yang sama, akan menunjukkan hasil yang selaras sebab kedua ayat tersebut adalah kebenaran mutlak, yang meskipun terjadi hasil yang berbeda, perbedaan itu terletak pada proses penelitian atau penafsirannya, bukan pada ayat-ayat Allah.

Penjelasan di atas dapat di lihat pada bagan berikut:

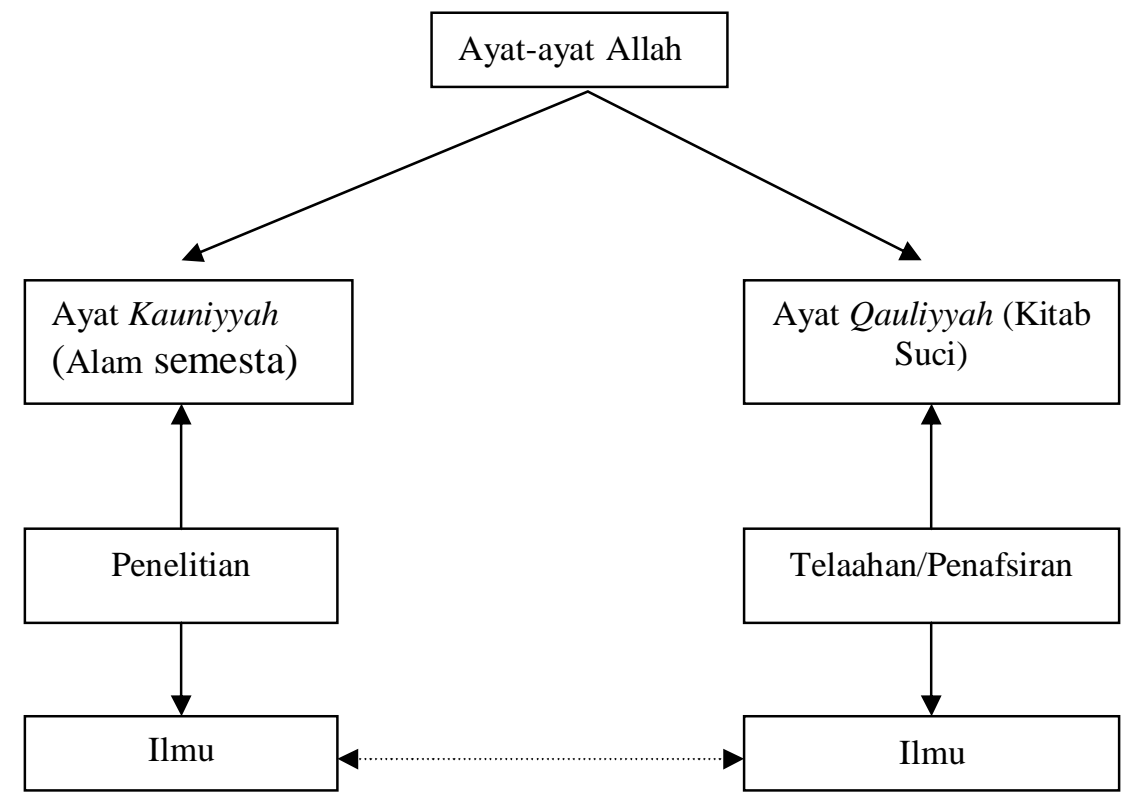

\section{Skema 1: proses penggalian ilmu}

Maksud penelitian ini adalah merintis konsep konseling berdasarkan Ayat-ayat Alquran. Prinsip nilai hubungan membantu tersebut yang dikaji dari ayat-ayat Alquran beranjak dari konsep dan 
falsafah konseling sekuler yang berkembang sekarang ini. Konseling sekarang ini boleh dikatakan merupakan hasil penelitian dan kajian dari ayat-ayat kauniyyah, sedangkan yang akan diteliti adalah ayatayat qauliyyah berdasarkan konsep konseling yang digali dari ayatayat kauniyyah. Menurut Ancok (dalam Bastaman,1997) bahwa jika kita ingin menghasilkan suatu pendekatan baru dalam khazanah ilmu pengetahuan, langkah yang paling tepat bukanlah memulainya dari nol melainkan harus dimulai dari penemuan terakhir.

Umat Islam yang fanatik dengan ajaran agamanya, apabila mengalami permasalahan psikologis, sangat membutuhkan pemecahan masalah dengan nilai-nilai ajaran Islam sendiri. Namun demikian, konsep konseling yang bersumber dari nilai-nilai ajaran Islam sampai saat ini, menurut penulis, belum tersaji secara konseptual dan sistematik, sehingga untuk menemukannya harus digali langsung dari sumber asli ajaran Islam itu sendiri, yaitu Alquran. Namun demikian, untuk dapat melakukan itu diperlukan waktu yang lama, kemampuan dan kejelian yang tinggi sebab ayatayat yang relevan dengan konseling belum terhimpun dan tersaji secara konseptual dan sistematis. Untuk itu, diperlukan terlebih dahulu pengkajian secara mendalam terhadap nilai-nilai ajaran Islam yang bersumber dari ayat-ayat Alquran.

\section{METODE PENELITIAN}

Penelitian ini adalah studi deskriptif-kualitatif dalam bentuk kajian pustaka dengan pendekatan analisis isi yang bersifat penafsiran (hermeneutik). Kajian pustaka berusaha mengungkapkan konsepkonsep baru dengan cara mambaca dan mencatat informasi, terutama yang bersumber dari ayat-ayat Alquran yang relevan, buku-buku teks, jurnal atau majalah-majalah ilmiah atau hasil-hasil penelitian dan sebaginya. Kajian ini dilakukan melalui lima tahap, yaitu (1) peneliti menelaah teori-teori hubungan interpersonal dan keterampilan komunikasi dalam pemberian bantuan atau konseling; (2) peneliti menemukan dan mengumpulkan ayat-ayat Alquran yang mengandung makna keterampilan komunikasi dalam konseling; (3) mengklasifikasi dan menetapkan ayat-ayat Alquran yang relevan dengan keterampilan komunikasi dalam konseling, menguraikan, mengklasifikasi dan menyusunnya secara sistematis. Untuk meyakinkan pengambilan dan penetapan ayat-ayat Alquran yang relevan dengan konsep 
keterampilan komunikasi dalam konseling serta keakuratan uraiannya, dilakukan uji ahli; (4) melakukan pembahasan dengan mensintesa kandungan pokok ayat-ayat Alquran dengan konsep pokok keterampilan komunikasi dalam konseling berdasar psikologi; dan (5) menyimpulkan bagaimana konsep keterampilan komunikasi dalam konseling yang bersumber dari ayat-ayat Alquran.

Tahap-tahap yang dilakukan dalam penelitian ini berpedoman pada tahap-tahap yang dikemukakan oleh Al-Faruqi (dalam Ancok \& Suroso 2001:118) yang menetapkan lima tahap sasaran dari rencana kerja islamisasi ilmu, yaitu (1) menguasai disiplin ilmu-ilmu modern; (2) menemukan khazanah Islam; (3) menemukan relevansi Islam yang spesifik pada setiap bidang ilmu pengetahuan modern; (4) mencari cara-cara untuk melakukan sintesa kreatif antara khazanah Islam dengan khazanah ilmu pengetahuan modern; dan (5) mengarahkan pemikiran Islam ke lintasan-lintasan yang mengarah pada pemenuhan pola rancangan Allah.

Aplikasi tahap-tahap pendekatan dan analisis yang digunakan dalam penelitian ini adalah sebagai berikut:

Pertama, menemukan konsep-konsep kunci dalam konseling tentang hakikat manusia, pola asuh, pribadi sehat, dan pribadi tidak sehat. Untuk tujuan ini, dilakukan langkah-langkah sebagai berikut: (1) menelaah teori-teori pendekatan konseling yang banyak digunakan dalam dunia pendidikan, yaitu psikoanalitik, terapi Adlerian, terapi eksistesial, terapi terpusat pada pribadi, terapi gestalt, analisis transaksional, terapi perilaku, terapi rasional-emotif, dan terapi realita. Teori-teori pendekatan konseling ini ditelaah dari buku Gerald Corey (1996) yang berjudul Theory and Practice of Counseling and Psychoterapy sebagai buku kajian utama dan ditunjang beberapa buku lain yang relevan. Buku ini dijadikan sebagai buku kajian utama karena buku ini menyajikan kesembilan teori pendekatan konseling tersebut secara sistematis; selanjtunya teori-teori tersebut ditelaah untuk menemukan persamaan dan perbedaannya, kemudian masingmasing teori dikelompokkan berdasarkan persamaan dan perbedaannya serta memberikan kesimpulan bagaimana kriteria pokok hakikat manusia, pola asuh, pribadi sehat, dan pribadi tidak sehat.

Kedua, mencari dan mengumpulkan ayat-ayat Alquran yang mengandung makna konsep kunci dalam konseling, yaitu hakikat 
manusia, pola asuh, pribadi sehat dan pribadi tidak sehat, dan hubungan membantu. Untuk ini dilakukan langkah-langkah sebagai berikut: (1) mencari dan mengumpulkan ayat-ayat Alquran yang mengandung makna konsep kunci dalam konseling dengan berpijak pada sifat dan kriteria sebagaimana langkah pertama; (2) melakukan penelusuran ayat-ayat Alquran dengan menggunakan indeks Alquran secara manual, dan melalui $C D$ Alquran $(6,50)$ versi Indonesia melalui komputer untuk menemukan ayat-ayat Alquran yang mengandung makna konsep kunci dalam konseling; dan (3) ayat-ayat yang ditemukan dikumpulkan dan dikelompokkan sesuai dengan topik yang dicari, untuk ditelaah lebih lanjut, mana ayat yang relevan dengan konsep kunci dalam konseling tentang keempat topik masalah yang telah ditetapkan.

Ketiga, menentukan dan menetapkan secara spesifik relevansi ayat-ayat Alquran dengan konsep kunci dalam konseling. Hal ini dilakukan melalui langkah-langkah berikut:

- menyeleksi ayat-ayat Alquran yang mengandung makna konsep kunci dalam konseling yang telah terkumpul pada langkah kedua dengan menetapkan ayat-ayat yang relevan dengan konsep kunci dalam konseling. Ayat-ayat yang dipilih memiliki karakteristik berikut:

\begin{tabular}{|c|c|c|}
\hline No & $\begin{array}{l}\text { IndikatorKomunikasi } \\
\text { Hubungan } \\
\text { Bersifat Membantu (konseling) } \\
\text { dalam Alquran }\end{array}$ & Kriteria \\
\hline 1. & $\begin{array}{l}\text { Ayat-ayat Alquran yang } \\
\text { memuat hubungan dialogis }\end{array}$ & $\begin{array}{l}\text { Adanya pihak yang diajak bicara } \\
\text { dengan pembicaraan antara satu } \\
\text { orang dengan orang, satu orang } \\
\text { dengan banyak orang, dengan } \\
\text { menggunakan } d \square \text { amîr mutakallim } \\
\text { dalam bahasa Arab seprti kata anâ, } \\
\text { antumâ, antum. }\end{array}$ \\
\hline 2. & $\begin{array}{l}\text { Ayat-ayat Alquran yang } \\
\text { memuat kronologis suatu } \\
\text { peristiwa }\end{array}$ & $\begin{array}{l}\text { Adanya fi'il mud } \square \text { âri' (menunjukkan } \\
\text { kejadian saat ini), adanya fi'il } \\
\text { mâd } \square i \text { (menunjukkan peristiwa masa } \\
\text { lalu), adanya maf'ûl bih yang } \\
\text { menunjukkan objek tindakan, sebuah } \\
\text { dialog yang menunjukkan urutan } \\
\text { kejadian secara sistematis dan }\end{array}$ \\
\hline
\end{tabular}


Thalib, Keterampilan Memberikan Perhatian...

\begin{tabular}{lll}
\hline & & berkesinambungan. \\
\hline & $\begin{array}{l}\text { Ayat-ayat Alquran memuat } \\
\text { adanya seseorang yang } \\
\text { bertindak sebagai pengarah. }\end{array}$ & $\begin{array}{l}\text { Ayata-ayat Alquran } \\
\text { menunjukkan adanya kata } \\
\text { permintaan dan permohonan, adanya } \\
\text { fi'il, fâ'il, maf'ûl bih, ism, dan } \\
\text { menunjukkan seseorang atau lebih. }\end{array}$ \\
\hline & $\begin{array}{l}\text { Adanya suatu peristiwa yang } \\
\text { dianggap mengganggu aktivitas } \\
\text { kehidupan seseorang, berupa } \\
\text { perasaan, pikiran atau } \\
\text { perbuatan. }\end{array}$ & $\begin{array}{l}\text { Adanya suatu masalah, gambaran } \\
\text { tingkah laku yang menyimpang, dan } \\
\text { penyebab munculnya penyimpangan. }\end{array}$ \\
\hline
\end{tabular}

- mengungkapkan kandungan ayat-ayat itu dengan menggunakan tafsirnya, baik dengan menghubungkan ayat satu dengan ayat yang lain, maupun mencari dukungan keterangan sunah nabi atau hadis nabi saw. dan memberikan komentar sehingga kandungan ayat tersebut dapat sisajikan secara konseptual dan sistematis;

- melakukan pemeriksaan teman sejawat (peer judgment) untuk meyakinkan kebenaran telaahan yang telah terkonsep berdasarkan makna bahasa Alquran dari segi bahasa arab: perubahan kata dan kalimat, dan pengutipan asbâb al-nuzûl dari buku terjemahan ke kitab aslinya (kitab kuning). Alasan pemilihan peer judgment ini karena yang dikaji adalah ayat-ayat Alquran yang mempunyai konsekuensi Ilahiyah, sehingga memerlukan kehati-hatian.

Keempat, melakukan sintesis kandungan ayat-ayat Alquran dengan konsep kunci dalam konseling, yaitu dengan mengungkap, menghubungkan, dan menggabungkan secara jelas kandungan ayatayat Alquran yang telah ditetapkan dengan konsep kunci dalam konseling, yaitu hakikat manusia, pola asuh, pribadi sehat, dan pribadi tidak sehat sehingga terlihat dengan jelas relevansi kandungan ayatayat Alquran dengan konsep kunci dalam konseling, apakah ada kesamaan, keselarasan atau perbedaan tetapi secara prinsip masih mengandung relevansi.

Kelima, membuat ketetapan akhir dengan menyimpulkan bagaimana konsep kunci dalam konseling berdasarkan ayat-ayat Alquran secara konseptual dan sistematis.

\section{PEMBAHASAN DAN ANALISIS}

Penilaian draf konsep keterampilan komunikasi dalam konseling ditinjau dari ayat-ayat Alquran tentang keterampilan menyiapkan, 
keterampilan memberikan perhatian, keterampilan mengamati, keterampilan mendengarkan, dan keterampilan memantulkan perasaan, diberikan kepada seorang ahli tafsir (ahli memaknai ayatayat Alquran) terhadap relevansi ayat dengan konsep pokok keterampilan komunikasi dalam konseling, dengan ketepatan pengambilan ayat, dan keakuratan dalam memaknai ayat.

Untuk memberikan penilaian relevansi ayat dengan konsep keterampilan komunikasi dalam konseling, kepada subjek ahli diberikan lima alternatif kriteria penilaian untuk setiap ayat, yaitu (1) sangat relavan (SR), (2) relevan (R), (3) cukup relevan (CR), (4) kurang relevan (KR), (5) tidak relevan (TR).

Hasil penilaian ahli tentang ayat-ayat Alquran berkaitan dengan keterampilan memberikan perhatian (attending skill), sesuai dengan kriteria penilaian seperti tersebut di atas, dapat dikemukakan sebagai berikut:

\begin{tabular}{lcccccc}
\hline Keterampilan & Jumlah Ayat & SR & R & CR & KR & TR \\
\hline $\begin{array}{l}\text { Memberikan } \\
\text { perhatian }\end{array}$ & 27 & - & 6 & 2 & 7 & 12 \\
\hline \multicolumn{1}{c}{ Makna } & dari & penilaian & $\mathrm{SR}=0$, & $\mathrm{R}=6$, & $\mathrm{CR}=2$ & tampaknya
\end{tabular}

keterampilan memberikan perhatian penting karena masih banyak ayat yang relevan. Memberikan perhatian terhadap tingkah laku orang itu penting, saat memberikan perhatian, pemberi bantuan perlu bersikap positif dalam arti merasa senang, akrab, hormat, rendah hati, sopansantun, empati, bijaksana, tulus-ikhlas terhadap orang yang diberi perhatian, tidak bersikap negatif, seperti tinggi hati, meremehkan, egois, dan tidak bertanggung jawab.

Pertama, ayat relevan (R). Contoh:

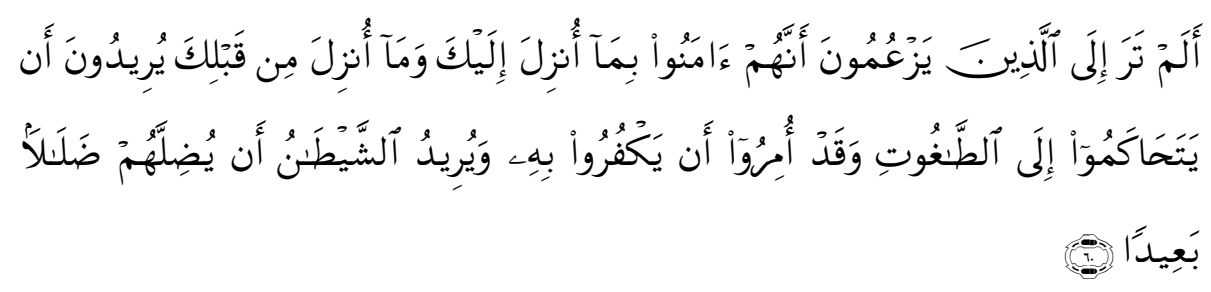

Terjemahnya:

Apakah kamu tidak memperhatikan orang-orang yang mengaku dirinya telah beriman kepada apa yang 
diturunkan kepadamu dan kepada apa yang diturunkan sebelum kamu? Mereka hendak berhakim kepada thaghut, padahal mereka telah diperintah mengingkari thaghut itu. Dan syaitan bermaksud menyesatkan mereka (dengan) penyesatan yang sejauh-jauhnya (Q.S Al-Nisâ'[4]:60).

Kedua, ayat cukup relevan (CR). Contoh:

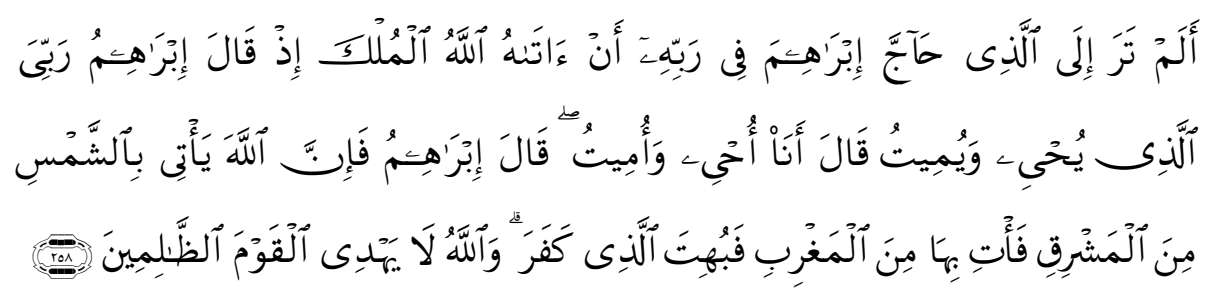

Terjemahnya:

Apakah kamu tidak memperhatikan orang yang mendebat Ibrahim tentang Tuhannya (Allah) karena Allah telah memberikan kepada orang itu pemerintahan (kekuasaan). Ketika Ibrahim mengatakan: "Tuhanku ialah Yang menghidupkan dan mematikan," orang itu berkata: "Saya dapat menghidupkan dan mematikan". Ibrahim berkata: "Sesungguhnya Allah menerbitkan matahari dari timur, maka terbitkanlah dia dari barat," lalu heran terdiamlah orang kafir itu; dan Allah tidak memberi petunjuk kepada orang-orang yang zalim (Q.S Al-Baqarah [2]:258).

Ketiga, memaknai tingkah laku dalam ayat.

Pesan yang disampaikan dalam Q.S surah Al-Nisâ' (4):60 \& 61, orang yang memberikan perhatian perlu bersikap positif. Artinya, memberikan perhatian dengan tulus walaupun orang yang diberi perhatian bersikap negatif (melakukan tindakan berbeda dengan keinginan kita), bersikap rendah hati, sopan menerima orang dengan apa adanya, santun dalam berbicara (meberikan ajakan), bijaksana memberikan ajakan.

\section{KONSEP KONSELING: MEMBERIKAN PERHATIAN}

Memberi perhatian yaitu tingkah laku pemberi bantuan yang menunjukkan bahwa mereka dalam kebersamaan pada saat berkomunikasi. Berdasarkan studi yang dilakukan Ivey (1968) 
memberi perhatian memiliki beberapa komponen yaitu: eye contact, posture, gesture, dan verbal behavior. Brammer (1973) menjelaskan bahwa tingkah laku verbal yang ditampilkan secara tepat oleh helper pada helpee sangat bermanfaat dan mendorong helpee untuk menyatakan ide-idenya atau perasaan-perasaannya secara bebas. Selain itu, dinyatakan bahwa tingkah laku memberi perhatian yang tepat juga memungkinkan keduanya (helper dan helpee) untuk mengekspresikan diri, memelihara hubungan dan mengembangkan rasa tanggung jawab pada proses komunikasi.

Kontak mata (eye contact), antara pemberi bantuan dan orang yang diberi bantuan merupakan unsur yang sangat penting dalam proses komunikasi (Carkhuff, 1983; Brammer, 1985). Dengan memandang yang diberi bantuan atau ditolong, pemberi bantuan atau penolong dapat mengamati keadaan yang dibantu, seperti keadaan jasmani, sikap, ekspresi wajah atau tanda-tanda nonverbal lainnya, semua yang dilihat itu memberi informasi pada pemberi bantuan atau penolong tentang keadaan yang dibantu atau klien.

Sikap tubuh (posture) dapat mendorong atau menghambat interaksi antarpribadi, biasanya sikap pemberi bantuan yang rileks, mengarah pada yang dibantu dan menunjukkan minat, akan menimbulkan perasaan positif pada diri yang diberi bantuan yaitu merasa mendapat perhatian dari pemberi bantuan (penolong) (Brammer, 1973; Terry, 1989). Pemberi bantuan sebaiknya mencondongkan tubuh bagian atasnya ke arah setiap orang yang diberi bantuan. Ketika duduk, pemberi bantuan harus merasa nyaman, dan ketika berdiri, dia harus mencondongkan tubuh bagian depan ke depan dan terlihat nyaman. Hal ini dimaksudkan untuk menyampaikan "Saya ingin (mempunyai kecenderungan) untuk membantu Anda" (Carkhuff, 1979).

Gerakan dan isyarat (gesture). Bagaimana gesture yang ditampilkan pemberi bantuan akan dikomunikasikan pada yang dibantu, pemberi bantuan hendaknya dapat menampilkan serta menunjukkan gesture yang siap untuk menerima pesan dari yang diberi bantuan (Brammer, 1973). Selanjutnya pemberi bantuan dapat mengamati gesture yang ditampilkan oleh yang dibantu, seperti: 
apakah yang diberi bantuan banyak gerakan tangannya dan sebagainya, semuanya itu mempunyai makna bagi pemberi bantuan (penolong).

Tingkah laku verbal (verbal behavior) yang ditampilkan oleh pemberi bantuan, erat kaitannya dengan apa yang telah dikatakan yang dibantu padanya. Jarak antara pemberi bantuan dan yang dibantu juga memberikan pengaruh pada komunikasi. Apakah jarak antara pemberi bantuan dan yang dibantu terlalu dekat, sehingga yang dibantu menjadi takut?. Apakah keduanya dalam jarak yang cukup menyenangkan, sehingga keduanya merasa aman dalam berkomunikasi. Jarak dapat dibedakan atas empat macam yaitu: (a) jarak intim antara 0-45 cm, (b) jarak pribadi antara 45-5 cm (fase dekat) dan antara 75-20 cm (fase jauh), (c) jarak sosial antara 120 $210 \mathrm{~cm}$ (fase dekat) dan antara 210-360 cm (fase jauh), dan (d) jarak publik antara 360-450 cm (Devito, 1997).

Jarak yang digunakan dalam hubungan komunikasi antarpribadi antara pemberi bantuan dan yang dibantu adalah jarak pribadi. Apakah pemberi bantuan akan menggunakan fase dekat atau fase jauh. Hal ini tergantung pada pemberi bantuan, dengan mempertimbangkan berbagai faktor lainnya yang mungkin turut mempengaruhi rasa aman disaat sedang berkomunikasi. Dengan menggunakan jarak pribadi pemberi, bantuan dapat melihat banyak hal tentang orang yang dibantu seperti: keadaan jasmani, gerakan tubuh dan sebagainya.

Dalam menerapkan berbagai komponen tersebut di atas, pemberi bantuan dapat memperhatikan petunjuk-petunjuk berikut: (1) tetapkanlah kontak dengan mengarahkan pandangan dalam batas yang wajar kepada orang yang dibantu ketika ia berbicara, (2) peliharalah postur tubuh yang rileks, yang menunjukkan bahwa pemberi bantuan berminat dengan pembicaraannya, (3) gunakah postur yang wajar, (4) gunakan pernyataan verbal yang sesuai dengan pernyataan orang yang diberi bantuan tanpa menyimpang dari arah pembicaraan.

Dari uraian di atas, dapat disimpulkan bahwa menempatkan posisi tubuh dengan penempatan yang wajar. Artinya, pemberi bantuan hendaknya mengerti keadaan orang yang diberi bantuan, jika yang diberi bantuan adalah laki-laki yang biasanya berbeda keadaanya dengan wanita. Oleh karena itu, memahami keadaan ini 
sangat penting bagi seorang pemberi bantuan sehingga tidak menimbulkan persepsi yang kurang baik bagi orang yang diberi bantuan, khususnya bagi klien wanita.

Selanjutnya keterampilan nonverbal adalah kemampuan menangkap arti reaksi ekspresi wajah, mimik, gerakan mata, tubuh, tangan, untuk kemudian dapat dilihat secara jelas apakah masalah esensi yang tengah terjadi dan yang perlu diatasi oleh pemberi bantuan atau konselor. Selengkapnya perilaku nonverbal yang seyogyanya diperhatikan oleh pemberi bantuan atau konselor adalah sebagaimana gambar berikut:

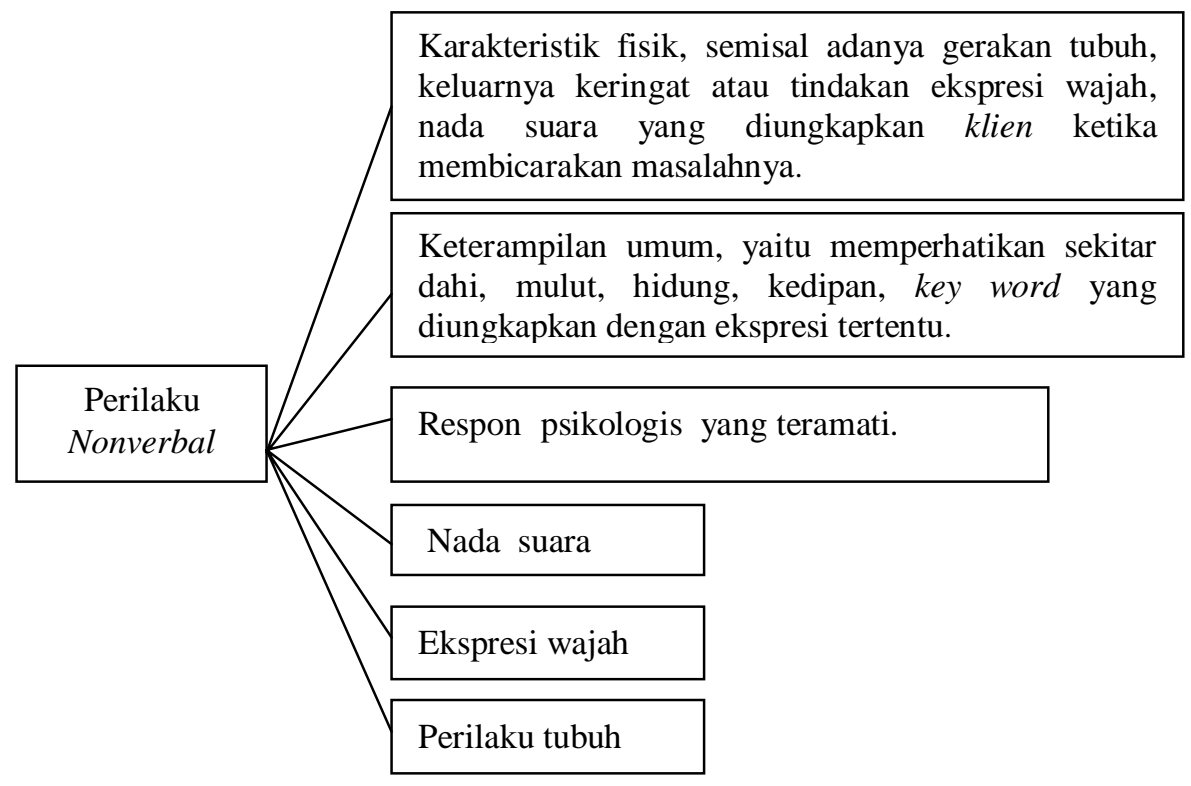

Skema 2. Perilaku nonverbal yang diamati selama proses komunikasi dalam konseling

Semakna dengan yang terdapat dalam gambar tersebut di atas adalah apa yang dikatakan oleh Carkhuff dengan istilah "pengamatan". Artinya memusatkan perhatian pada semua hal yang terdapat pada wajah orang yang diberi bantuan. Mengamati mempunyai dua tujuan, yaitu (1) mendorong ungkapan verbal orang yang diberi bantuan dengan memberi sinyal sikap perhatian dan sikap atentif dari pemberi bantuan; dan (2) memungkinkan pemberi bantuan belajar banyak mengenai pribadi orang yang diberi bantuan melalui 
penyerapan informasi visual. Lima bidang khusus yang menjadi titik pengamatan, yaitu bentuk badan, postur, perawatan diri, fokus (arah perhatian orang yang diberi bantuan), serta ungkapan nonverbal berkelanjutan (Carkhuff, 1979).

Berdasarkan uraian di atas, dapat disimpulkan bahwa kegiatan memberikan perhatian yang dilakukan oleh pemberi bantuan berupa persiapan dan positioning, membuat orang yang diberi bantuan memasuki keterlibatan awal dalam proses pemberian bantuan. Pengamatan pemberi bantuan akan mendorong orang yang diberi bantuan memberikan respons dari ungkapan nonverbal ke ungkapan verbal sekaligus memberi kesempatan kepada pemberi bantuan untuk mengumpulkan data-data visual dari kesimpulan-kesimpulan sementara. Akan tetapi, pemberi bantuan untuk sementara waktu belum terlibat secara penuh. Pemberi bantuan dapat mendorong tercapainya tingkat keterlibatan akhir orang yang diberi bantuan dengan cara terus-menerus mengamati orang yang diberi bantuan, dan pada saat yang sama, menggunakan keterampilan mendengarkan orang yang diberi bantuan.

\section{MEMBERIKAN PERHATIAN: TELAAH AYAT ALQURAN}

Memberikan perhatian (attending skill) adalah tingkah laku pemberi bantuan yang menunjukkan bahwa mereka dalam kebersamaan pada saat berkomunikasi. Dalam konteks ini, memberikan perhatian dengan meggunakan indra mata (makna dari kata $r a^{\prime} \hat{a}$ ). Memberikan perhatian memiliki beberapa komponen, yaitu (1) memusatkan pandangan (kontak mata); (2) memperhatikan sikap tubuh/perbuatan; (3) meperhatikan perkataan atau nada suara; (4) memperhatikan penempatan posisi; dan (5) melakukan pembicaraan tuntas. Kelima poin di atas diuraikan sebagai berikut:

Pertama, memusatkan pandangan (kontak mata), yaitu pemberi bantuan memusatkan pandangannya pada orang yang diberi bantuan, seperti: keadaan jasmani, sikap, ekpresi wajah, atau tanda-tanda nonverbal lainnya, ini dimaksudkan agar apa yang dilihat itu dapat memberikan informasi bagi pemberi bantuan tentang keadaan orang yang diberi batuan.

Kedua, memperhatikan sikap tubuh, yaitu pemberi bantuan melihat kepada orang yang diberi bantuan dari segi fisiknya melalui gerakan tubuhnya dan segala sesuatu yang tampak dari wajahnya 
seperti: wajah murung, tatapan mata yang kosong, wajah ceria, senyum dan sebagainya. Selain memperhatikan sikap tubuh orang yang diberi bantuan, pemberi bantuan juga perlu memperhatikan sikap tubuhnya, seperti: merasa nyaman ketika duduk, mencondongkan tubuh bagian atasnya ketika duduk maupun ketika berdiri, kedepan atau kearah orang yang diberi bantuan. Ini merupakan isyarat untuk menyampaikan bahwa "pemberi bantuan ingin membantu Anda".

Ketiga, memperhatikan perkataan atau nada suara, yaitu pemberi bantuan memperhatikan perkataan disertai dengan nada suara pada saat berbicara. Perkataan yang disertai dengan nada suara yang rendah, menunjukkan rendahnya keterlibatan, tetapi perkataan yang diucapkan dengan nada suara yang tinggi, menunjukkan tingginya tingkat keterlibatan orang yang diberi bantuan. Di sisi lain, perkataan yang disertai dengan nada suara yang tinggi menunjukkan bahwa masalah yang akan dibicarakan adalah masalah yang serius.

Keempat, memperhatikan penempatan posisi, yaitu pemberi bantuan perlu memperhatikan jarak atau kedekatan pada waktu berbicara dengan orang yang diberi bantuan. Dalam pemberian bantuan, jarak yang sebaiknya adalah jarak pribadi. Jarak ini sebagaimana dicontohkan pada waktu melaksanakan salat berjamaah, antara imam salat dan makmum menggunakan jarak pribadi ini (jaraknya antara 70-100 cm). Pemberi bantuan juga sedapat mungkin mengambil posisi pada ketinggian yang sama dengan orang yang diberi bantuan, seperti posisi imam salat dengan makmumnya yang selalu berada pada ketinggian yang sama. Tujuannya adalah (1) pemberi bantuan dapat melihat wajah orang yang diberi bantuan dengan baik, (2) pemberi bantuan dapat berkomunikasi setara dengan orang yang diberi bantuan, yang mempunyai kesamaan dengan tujuan dalam salat berjamaah, yaitu pada saat jamaah melakukan salam ke kanan dan ke kiri sebagai pertanda salat telah selesai dilakukan. Selanjutnya, posisi pemberi bantuan dalam posisi sudut. Pemberi bantuan dengan orang yang diberi bantuan pada posisi yang berbentuk persegi panjang, seperti posisi orang yang sedang melakukan zikir setelah salat berjamaah, imam berbalik ke belakang menghadap makmum. Demikian pula pada saat melakukan mudhâkarah agama, jamaah saling berhadapan dengan bentuk persegi panjang, lengan 
kanan pemberi bantuan dengan orang yang diberi bantuan saling bersilangan secara langsung dengan lengan kiri (pria dengan pria).

Kelima, melakukan pembicaraan tuntas, yaitu mengikuti topik pembicaraan orang yang diberi bantuan dengan tuntas. Maksudnya, pemberi bantuan mengikuti secara cermat topik pembicaraan orang yang diberi bantuan tanpa mengubah atau menggantinya dengan topik yang lain. Misalnya, topik pembicaraan orang yang diberi bantuan adalah masalah ibadah, maka pemberi bantuan juga berbicara mengenai topik ibadah, dan tidak mengganti topik tersebut dengan topik muamalah atau muasyarah dan seterusnya.

\section{PENUTUP}

Keterampilan memberikan perhatian dalam konteks konseling memiliki lima komponen, yaitu (1) kontak mata, (2) sikap tubuh, (3) gerakan dan isyarat, (4) tingkah laku verbal, dan (5) topik pembicaraan. Dalam telaah ayat Alquran tentang memberikan perhatian (attending skill) terdapat lima komponen yang harus diperhatikan, yaitu (1) pandangan, (2) sikap tubuh/perbuatan, (3) perkataan atau nada suara, (4) penempatan posisi, dan (5) pembicaraan tuntas. Kelima komponen ini dipahami dari beberapa ayat Alquran dengan kata kunci ra'â yang artinya memperhatikan.

Hasil telaah ayat Alquran terhadap keterampilan memberikan perhatian dalam konseling menunjukkan bahwa terdapat kesamaan makna setiap komponen dalam memberikan perhatian, walaupun dalam peristilahan terdapat perbedaan. Hasil telaah juga menunjukkan bahwa di dalam ayat Alquran terdapat keterampilan komunikasi konseling yang memungkinkan untuk ditelaah dan dapat digunakan dalam menciptakan keterampilan komunikasi konseling islami.

Keterampilan memberikan perhatian dalam Alquran adalah suatu hal yang penting akrena banyak ayat Alquran yang relevan dengan keterampilan tersebut. Oleh karena itu, keterampilan memberikan perhatian merupakan keharusan bagi pendidik (guru, pembimb.g, penasihat akademik, dan konselor).

\section{DAFTAR PUSTAKA}

Ancok, J. \& Suroso, F.N. 2000. Psikologi Islami. Yogyakarta: Pustaka Pelajar

Bastaman, HD. 1997. Integrasi Psikologi dengan Islam: Menuju Psikologi Islami. Yogjakarta: Pustaka Pelajar. 
Brammer, L.M. 1995. The Helping Relationship (Proses and Skill). New Jersey: Prentice-Hal, Inc.

Corey 1996. Theory and Praktice of Counseling and Psychotherapy. Fifth edition. California: Books/Cole Publishing Company, Monterey. .1995. Teori dan Praktek dari Konseling dan Psikoterapi. Edisi ke-4. Terjemahan oleh Mulyarto \& Satmoko. Semarang: IKIP Semarang Press.

Cormier W.H. \& Cormier, L. 1991. Interviewing Strategies for Helpers. California: Brooks/Cele Publishing Company.

Carkhuff, Robert. R. 1977. The Art of Helping. Palmerston North: Human Resource Developing Press, Inc.

Carkhuff, Rober R., \& Anthony 1979. The Skill of Helping. Palmerston North: Human Resource Developing Press, Inc.

Departemen Agama RI. 2002. Alquran dan Terjemahnya. Surabaya: AlHidayah.

Devito, A. Joseph. 1997. Komunikasi Antarmanusia. Terjemahan oleh Agus Maulana, MSM. Jakarta: Profesional Books.

Egan, Gerard. 1975. The Skilled Helper: A. Model for Systematic Helping and Interpersonal Relating. Monterey, California: Brooks/Cele Publishing Company.

Genia, V. 1994. Secular Psychotherapists and Relegious Client: Professional Considerations and Recommendations. Journal of Counseling and Development. (72): 395-398.

Ivey G. 1975. Microcounseling: Innovations in Interview Training. Springfield III: Thomas.

Krippendorff Klaus. 1993. Analisis Isi Pengantar Teori dan Metodologi. Jakarta: PT. Raja Grafindo Persada.

Keating, A.M. \& Fretz, B.R. 1990. Cristian Anticipation About Counselors in Response to Counselor Descriptions. Journal of Counseling Psychology. (37): 293-296.

Stanard, R. P, Daya S. S, \& Linda C. P. 2000. Assesment of Spirituality in Counseling. Journal of Counseling \& Development. 78 (2): 204. 